\title{
PENINGKATAN PARTISIPASI MASYARAKAT DALAM PENGELOLAAN POTENSI DESA BERBASIS IPTEK DI DESA BALUK
}

\author{
I.K. A. Atmika ${ }^{1}$, I.G.A.K. Suriadi ${ }^{2}$, I.D.G.A. Subagia ${ }^{3}$
}

\begin{abstract}
ABSTRAK
Tema dari program KKN-PPM di desa Baluk adalah Pemberdayaan dan Peningkatan partisipasi masyarakat dalam pengelolaan potensi desa berbasis Iptek menuju desa yang Mandiri, melalui program program seperti program kesehatan masyarakat: penyuluhan sanitasi rumah tangga dan penyuluhan pola hidup bersih dan sehat pada anak-anak sekolah. Program lingkungan: melelui kegiatan penghijauan di areal sepanjang jalan desa. Peningkatan produktivitas masyarakat/kelompok usaha dalam produksi susu kedelai melalui pengenalan dan penerapan teknologi mesin blender. Efisiensi biaya dengan pengenalan dan penerapan teknologi digester biogas/biogas portable dengan pemanfaatan kotoran sapi untuk sumber energi sehar-hari. Peningkatan partisipasi masyarakat dalam semua kegiatan KKN-PPM. Peningkatan swadaya masyarakat dalam melanjutkan setiap program yang telah didampingi selama kegiatan KKN-PPM. Metode pelaksanaan kegiatan dibagi menjadi tiga tahapan. Tahapan pertama adalah persiapan dan pembekalan, tahap kedua implementasi kegiatan di lapangan, dan tahap ketiga evaluasi dan monitoring untuk koreksi dan penyempurnaan keberlanjutan program. Tahap persiapan dimulai dengan dosen pembimbing lapangan dan mahasiswa audensi dengan aparat desa dan tokoh masyarakat untuk menentukan skala prioritas kegiatan berdasarkan kondisi dan potensi yang ada di masyarakat, kegiatan ini dilaksanakan pada tanggal 20 Juli 2017.Tahap implementasi pelaksanaan kegiatan dilakukan dengan penyuluhan maupun praktek di lapangan, maupun pendampingan oleh mahasiswa peserta KKN selama di lapangan. Kegiatan pengabdian dilaksanakan selama satu bulan dimulai tanggal 22 Juli 2017 sampai dengan 27 Agustus 2017. Sedangkan tahap ketiga adalah evaluasi dan monitoring dilakukan oleh tim pelaksana/dosen pembimbing lapangan dan koordinator KKN untuk melihat dampak dan keberlanjutan program yang sudah dilaksanakan.
\end{abstract}

Kata Kunci : Pemberdayaan, Peningkatan partisipasi masyarakat, potensi desa, iptek, biogas portable.

\begin{abstract}
The themes of the KKN-PPM program in Baluk village are: Empowerment and Improvement of community participation in the management of the potential of science and technology-based villages to Mandiri villages through programs such as: public health programs: household sanitation counseling and counseling of clean and healthy lifestyle in children. school children. Environmental program: reforestation activities in the area along the village road. Increased productivity of community / business groups in the production of soy milk through the introduction and application of blender machine technology. Cost-efficiency with the introduction and
\end{abstract}

\footnotetext{
${ }^{1}$ Staf Pengajar Jurusan Teknik Mesin Fakultas Teknik Universitas Udayana, tutadi2001@yahoo.com

${ }^{2}$ Staf Pengajar Jurusan Teknik Mesin Fakultas Teknik Universitas Udayana

${ }^{3}$ Staf Pengajar Jurusan Teknik Mesin Fakultas Teknik Universitas Udayana
} 
application of biogas / biogas portable biogas technology with the use of cow dung for a day-to-day energy source. Increased public participation in all KKN-PPM activities. Increased community self-reliance in continuing every program that has been accompanied during KKN-PPM activities. Method of implementation of activities is divided into three stages. The first stage is preparation and briefing, second phase of implementation of activities in the field, and third stage evaluation and monitoring for correction and refinement of program sustainability. Preparatory phase begins with field supervisors and students with the village apparatus and community leaders to determine the priority scale of activities based on the conditions and potentials that exist in the community, this activity was held on July 20, 2017. The implementation of activities carried out with counseling and practice in the field, as well as mentoring by students participating KKN during the field. The dedication activity is held for one month starting from July 22, 2017 until August 27, 2017. While the third stage is the evaluation and monitoring conducted by the team of field supervisors and coordinators of KKN to see the impact and sustainability of programs that have been implemented.

Keywords: Empowerment, Increased community participation, village potential, science and technology, portable biogas.

\section{PENDAhUluan}

Desa Baluk terletak di kecamatan Negara, kabupaten Jembrana Provinsi Bali. Desa ini memiliki luas wilayah menurut penggunaan yaitu 791,5 hektar dengan jumlah penduduk 6465 orang (BPS Kabupaten Jembrana, 2013), dan berbatasan dengan empat bagian daerah yaitu; sebelah utara berbatasan dengan Desa Banyubiru dan desa Kaliakah, sebelah selatan berbatasan dengan Cupel dan desa Tegal Badeng, sebelah timur berbatasan dengan desa Lelateng, serta sebelah barat berbatasan dengan desa Banyubiru dan laut. Secara administrasi desa Baluk membawahi empat banjar dinas yaitu: banjar Baluk I, banjar Baluk II, banjar Anyar, banjar Jati, dan banjar Rening.

Penduduk tersebar di kelima banjar dinas tersebut dengan menyisakan beberapa permasalahan, daerah bagian selatan dari desa Baluk untuk semua banjar paling banyak timbul permasalahan antara lain: permasalahan kesehatan masyarakat: belum tersedianya air bersih secara merata untuk seluruh masyarakat desa, terbatasnya masyarakat yang memiliki sanitasi rumah tangga dan kurangnya pemahaman masyarakat tentang pola hidup bersih dan sehat terutama pada anak-anak sekolah. Produktivitas masyarakat masih rendah, contoh dalam produksi susu kedelai, kelompok usaha masih memproduksi secara konvensional. Berlimpahnya potensi energy alternative didesa yang belum termanfaatkan dengan baik, khususnya energy biogas dari kotoran ternak, sehingga dengan pengenalan dan penerapan teknologi digester biogas kotoran hewan (sapi, babi) menjadi sumber energi sehari-hari.

\section{METODE PEMECAHAN MASALAH}

Untuk mengatasi permasalahan masyarakat dan dalam melaksanakan pemecahan permasalahan masyarakat digunakan beberapa metode antara lain:

- Metode penyuluhan, penyuluhan dilakukan untuk memberikan pemahaman tentang kegiatan yang dilaksanakan dan meningkatkan pengetahuan masyarakat terhadap hal-hal dibicarakan.

- Metode pendampingan, untuk menindaklanjuti pengetahuan yang diberikan ke masyarakat dengan terlibat secara langsung dengan masyarakat dalam setiap kegiatan.

- Metode gotong royong, melakukan kegiatan secara bersama-sama dengan masyarakat pemuda dan anak-anak.

\section{1 | BULETIN UDAYANA MENGABDI}


- Metode penerapan teknologi tepat guna (TTG), langsung bersama masyarakat membuat/membangun suatu teknologi yang mudah, murah dan berdaya guna.

\section{HASIL DAN PELAKSANAAN KEGIATAN}

Kegiatan pengabdian masyrakat KKN PPM di lapangan/desa dilaksanakan dari tanggal 22 Juli 2017 sampai 27 Agustus 2017. Untuk memudahkan koordinasi pelaksanaan kegiatan KKN PPM, kegiatan dikelompokkan menjadi empat bidang yaitu, bidang Prasarana Fisik (PF), Bidang Peningkatan Produksi (PP), Bidang Sosial Budaya (SB) dan Bidang Kesehatan Masyarakat (KM).

\section{Kegiatan Bidang Prasarana Fisik}

a. Pembuatan Tong Sampah

b. Gotong Royong

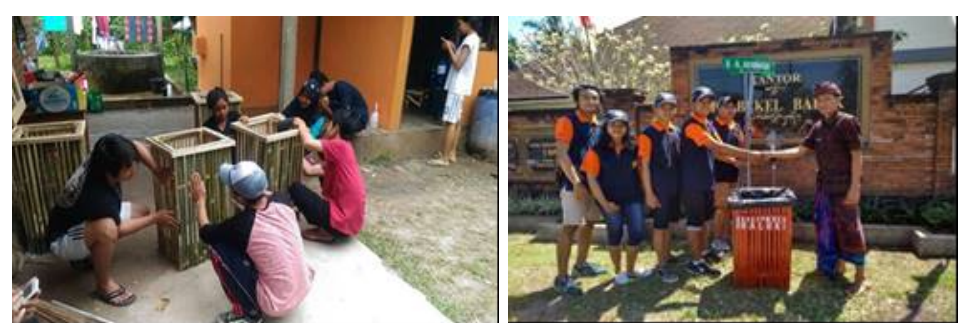

Gambar 3.1. Pembuatan dan Serah Terima Tempat Sampah

\section{Kegiatan Bidang Peningkatan Produksi}

a. Penyuluhan dan Pengadaan Bahan dan Alat Pengoptimalan Biogas (desulfuriser dan genset biogas)

b. Penyuluhan dan demo pengolahan kotoran ternak menjadi pupuk organik

c. Penyuluhan dan demo pemanfaatan jerami menjadi pakan ternak

d. Pelayanan Kesehatan Ternak

e. Penerapan mesin blender susu kedelai di kelompok usaha wanita Taman Sari
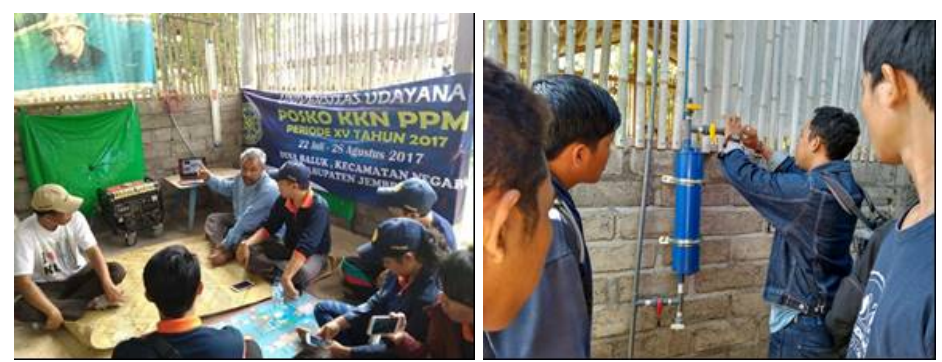

Gambar 3.2. Peyuluhan, Pemasangan desulfuririzer dan genset biogas 

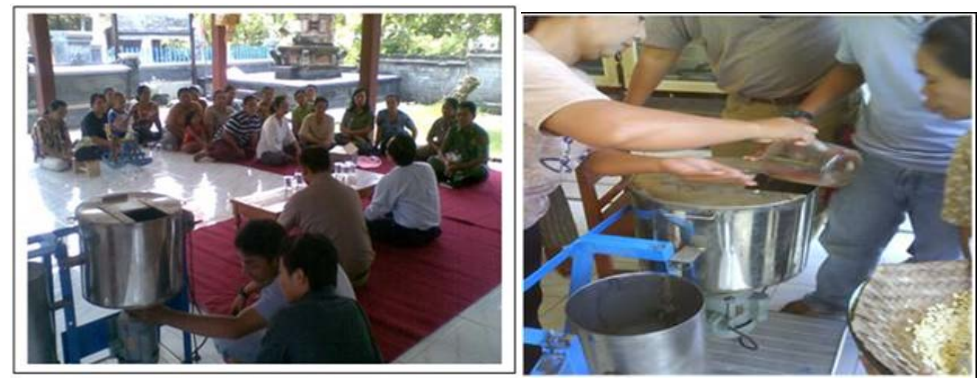

Gambar 3.3. Aplikasi mesin blender di kelompok usaha
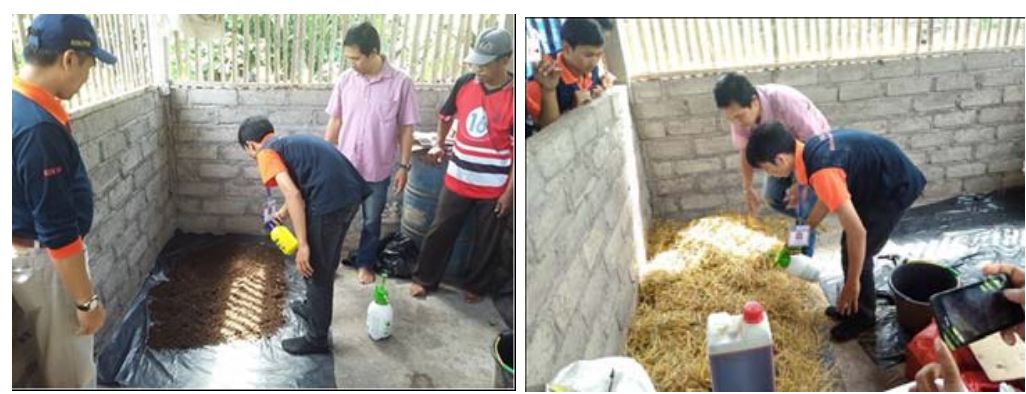

Gambar 3.4. Peyuluhan dan demo pengolahan pakan ternak dan pupuk organik

\section{Kegiatan Bidang Sosial Budaya}

a. Restorasi Promosi Daya Tarik Wisata Pantai Baluk Rening

b. Ngayah dan Gotong Royong di Pura Majapahit

c. Kegiatan Membantu Mengajar Anak SD

d. Membantu acara 17 Agustusan di Desa Baluk
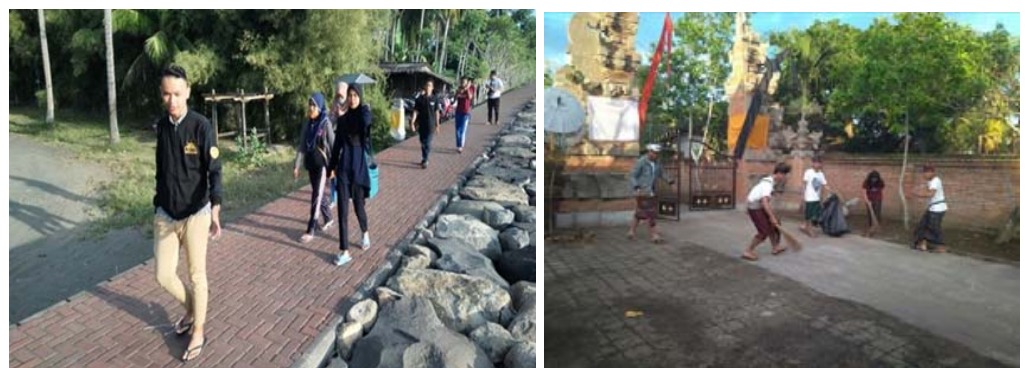

Gambar 3.5. Promosi pariwisata pantai Rening dan gotong royong

\section{Kegiatan Bidang Kesehatan Masarakat}

a. Sosialisasi BPJS Ketenagakerjaan pada Pekerja Bukan Penerima Upah (BPU)

b. Sosialisasi PHBS dan Praktek Cuci Tangan dengan Sabun

c. Penyuluhan Perilaku Keselamatan Berkendara (Safety Riding)

d. Posyandu Balita.

e. Pelayanan Kesehatan Lansia 

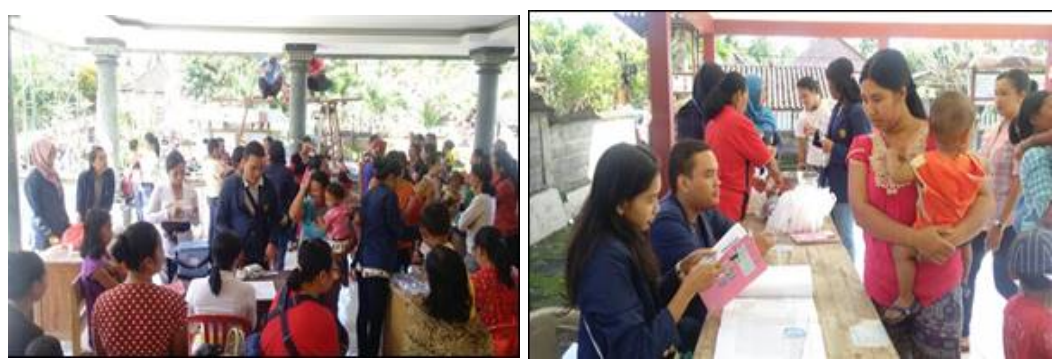

Gambar 3.6. Kegiatan Posyandu Bayi dan Balita di Desa Baluk

\section{SIMPULAN DAN SARAN}

Adapun kesimpulan yang bisa diambil dalam kegiatan pengabdian ini adalah:

- Tim telah berhasil memotivasi gapoktan dalam mengelola potensi biogas, potensi pakan ternak alternativ, potensi kotoran ternak menjadi pupuk organik sehingga lebih optimal.

- Pelatihan pengolahan pupuk dengan RB memotivasi petani dan kelompok ternak untuk menghasilkan pupuk secara mandiri.

- Pelatihan pengolahan pakan ternak dengan Biochast memotivasi petani dan kelompok ternak untuk menghasilkan pakan ternak dari limbah jerami.

- Melalui pengabdian ini terdapat tukar informasi antara tim sebagai akademisi di kampus dengan masyarakat, aparatur desa/banjar, dan para pengusaha pengusaha kecil di desa dalam meningkatkan potensi mereka.

Ada beberapa hal yang disarankan dalam melaksanaan pengabdian ini, yaitu:

- Berdasarkan fakta dilapangan, hendaknya masing-masing anggota memiliki tugas yang pasti karena selama ini pengerjaan dilakukan berdasarkan kehadiran anggota sehingga tugasnya jadi tidak teratur.

- Pelaksanaan Pengabdian Masyarakat mendatang hendaknya perlu terus ditingkatkan, terutama dalam pembiayaan agar dapat benar-benar dapat membuat sesuatu yang baik.

\section{UCAPAN TERIMAKASIH}

Artikel ini disusun dari kegiatan pengabdian yang merupakan hibah KKN PPM yang didanai dari dana Dikti tahun 2017. Untuk itu penulis menyampaikan terima kasih yang sebesar-besarnya atas dukungan dana kegiatan pengabdian ini. Terima kasih juga disampaikan kepada LPPM Universitas Udayana yang mendukung dan memfasilitasi kegiatan penelitian dan pengabdian masyarakat untuk semua skema hibah.

\section{DAFTAR PUSTAKA}

Astawa P.A, Mahardika Gede, Budaarsa K., Budiasa K.M. 2013. Sosialisasi Pengolahan Pakan Dan Kotoran Ternak Dengan Teknologi Biofermentasi. Udayana Mengabdi 12 (2): 47 - 50.

BPS Kabupaten Jembrana. 2013. Negara Dalam Angka 2013.

http://jembranakab.bps.go.id/publikasi/2012/kecamatan_negara_dalam_angka_2013/Tanggal Akses 02 Pebruari 2014.

Budi A., Tim Ricardo, 2004, Penuntun Pengolahan Kedelai, Ricardo Off., Jakarta.

Budiono B., 1992, Industri Kecil dalam Perspektif Budaya, Seminar Prospek Industri Kecil Dalam Perkembangan Perekonomian Indonesia, Surabaya.

Dillon HS. 2004. Pertanian Mandiri. Penebar Swadaya. Jakarta.

Fahri Anis. 2009. Teknologi Pembuatan Biogas dari kotoran ternak. http: riau.litbang.deptan.go.id. Tanggal Akses 02 Maret 2014.

Hikmat, Harry. 2001. Strategi Pemberdayaan Masyrakat. Bandung, Humaniora Utama Press. 
Muchataridi, 2008, Pembuatan Susu Kedelai, Fakultas Farmasi Universitas Padjadjaran, Jawa Barat. Purba, Jusnita Nuriati. 2008. Pemberdayaan Masyarakat Desa Di Kecamatan Panombeian Panei Kabupaten Simalungun. Universitas Sumatra Utara.

Sekretariat daerah kabupaten Jembrana. 2015. Rencana program jangka menengah daerah kabupaten Jembrana. Negara.

Soebarinoto. 1997. Studi Potensi Hijauan pakan dalam Rangka Pengembangan Sapi Perah di Grati. Buletin Peternakan. $2: 142$.

Subanar Harimurti, 1992, Alternatif Pengembangan Industri Kecil/Kerajinan Surabaya, Seminar Prospek Industri Kecil Dalam Perkembangan Perekonomian Indonesia, Surabaya.

Sumodiningrat, Gunawan. 1997. Pembangunan Daerah dan Pemberdayaan Masyarakat. Jakarta. Bina Rena Pariwara.

Sunaryo. 2014. Rancang Bangun Reaktor Biogas Untuk Pemanfaatan Limbah Kotoran Ternak Sapi Di Desa Limbangan Kabupaten Banjarnegara. Jurnal PPKM UNSIQ 1(1): 21-30 